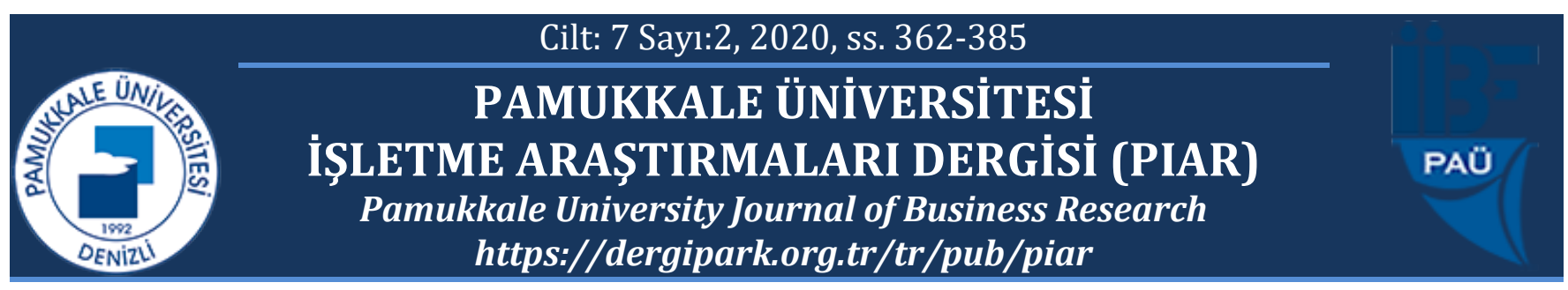

\title{
Sosyal Medyada Yükselen Bir Trend: Influencer Pazarlama Üzerine Kavramsal Bir Değerlendirme
}

\section{A Rising Trend in Social Media: A Conceptual Assessment on Influencer Marketing}

\section{Yasemin GEDİK ${ }^{*}$}

\author{
${ }^{1}$ Beykent Üniversitesi, Sosyal Bilimler Enstitüsü, İşletme Yönetimi Ana Bilim Dalı, dr.yasemingedik@hotmail.com, \\ https://orcid.org/0000-0002-1166-3227 \\ * Yazışılan Yazar/Corresponding author
}

\section{Öz}

Dijitalleşme ve internetin artan kullanımı nedeniyle, giderek daha fazla insan birbirleriyle iletişim kurmak için sosyal medyayı kullanmaktadır. Günümüzde 3,6 milyardan fazla kişi tarafindan kullanılan sosyal medyanın popülerliği, işletmeleri ürün ve hizmetlerini tanıtmak için bu platformlarda etkili fikir liderleriyle iş birliğine yöneltmektedir. Influencer pazarlama, bir markanın mesajın daha büyük kitlelere ulaştırmak için belirli bir hedef kitle üzerinde etkisi olan bireyleri kullanmaya odaklanan bir pazarlama türüdür. Issletmeler, bilgileri, konumları ve ilişkileri nedeniyle başkalarını satın alma kararın etkileyebilen kişiler olan influencer'lar ile ürün yerleştirme, marka onayları ve içerik oluşturma için çalışabilmektedir. Influencer pazarlama işletmelere, yüksek yatırım getirisi, marka farkındalığı ve satışları arttırma, potansiyel müşterileri elde etme, ürün ve hizmetlerini daha geniş kitlelere duyurabilme ve sosyal medya katılımin arttırma gibi önemli avantajlar sunabilmektedir. Influencer pazarlama, dünya çapında işletmelerin gün geçtikçe daha fazla ilgisini çekmekte ve influencer pazarlama stratejisini pazarlama seçeneklerinin önemli bir parçası olarak görmelerine neden olmaktadır. Bu çalışma, influencer pazarlama ile ilgili geniş bir kavramsal çerçeve oluşturmaya odaklanmaktadır. Ayrıca çalışma, influencer pazarlama stratejilerinden de bahsederek ilgili kararları alırken işletme yöneticilerine ve pazarlamacılara yardımo olmayı amaçlamaktadır.

Anahtar kelimeler: Influencer pazarlama, A ğızdan ă̆ıza pazarlama, Influencer pazarlama stratejileri

JEL kodlart: M10, M30, M31

\begin{abstract}
Due to digitization and the increasing use of the internet, more and more people are using social media to communicate with each other. The popularity of social media, used by more than 3.6 billion people today leads businesses to collaborate with influential opinion leaders on these platforms to promote their products and services. Influencer marketing is a type of marketing that focuses on using individuals who have an influence on a specific target audience to convey a brand's message to larger audiences. Businesses can work for product placement, brand approvals and content creation with influencers, who can influence the purchasing decision of others due to their knowledge, location and relationships. Influencer marketing can offer businesses significant advantages such as high return on investment, increased brand awareness and sales, getting potential customers, promoting their products and services to a wider audience and increasing social media engagement. Influencer marketing is attracting more and more attention of businesses around the world, causing them to see the influencer marketing strategy as an important part of their marketing options. This study focuses on creating a broad conceptual framework for influencer marketing. In addition, the study aims to help business managers and marketers while making relevant decisions by mentioning influencer marketing strategies.
\end{abstract}

Keywords: Influencer marketing, Word-of-mouth marketing, Influencer marketing strategies

JEL codes: $M 10, M 30, M 31$ 


\section{GİRIŞ}

Modern teknolojilerin ve özellikle internetin tüm uygulamaları ile hızlı gelişimi hem bireyler hem de işletmeler için birçok yeni fırsat sunmaktadır. Özellikle, sürekli yenilenen sosyal medya platformları ve bloglar insanlara çevrimiçi olarak aktif olma ve içerik oluşturma imkânı vermektedir (Ewers, 2017: 1). Facebook, YouTube ve Instagram gibi sosyal medya platformları yoğun kullanıcı davranışları nedeniyle birçok işletmenin müşteri iletişiminin ayrılmaz bir parçası haline gelmiştir ve influencer pazarlamaya giderek daha fazla bütçe ayırılmaktadır (Riedl ve Von Luckwald, 2019: 2). Influencer pazarlama, tüketicilerin tutumlarını ve karar alma süreçlerini markalar veya fikirler lehine etkileyebilen, iyi takip edilen çevrimiçi kullanıcılardan yararlanan bir pazarlama uygulamasıdır (Femenia-Serra ve Gretzel, 2020: 65).

Etkileme sorunu, pazarlama ve iletişim alanlarında çok uzun zamandan beri tartışılmaktadır. Etki teorileri, toplumu, bilgiyi yayabilen ve etkili olan sınırlı sayıda birey tarafından yönlendirilebilecek bir grup olarak algılamıştır. 1903'te Trade, insanların fikirleri popülerleştirmesini sağlayan iki süreç tanımlamıştır: Taklit ve etkileme (Szczurski, 2017: 1). Influencer pazarlama, etki teorisine dayanır ve etkili bireylerin küçük bir yüzdesinin, büyük toplulukları ikna etmede etkili olabileceği fikrini savunur. Influencer pazarlama, büyük bir tüketici grubuna yönelik pazarlama yapmak yerine, bir markanın mesajını daha geniş pazara yönlendirmek ve satın alma kararlarını etkilemek için etkili bireyleri kullanır. Influencer pazarlama, ilk zamanlarda, gazeteciler veya endüstri analistleri gibi çevrimdışı fikir liderlerine odaklansa da dijitalleşme ve Web 2.0'ın başarısıyla odağını çevrimiçi fikir liderlerine kaydırmıştır (Braatz, 2017: 6).

Influencer pazarlama, geleneksel reklamcılığa göre daha uygun maliyetlidir ve aynı zamanda, daha ilgili ve spesifik bir kitleye ulaşmaktadır (Claesson ve Ljungberg, 2018: 26). Yüksek yatırım getirisi, güvenilir içerik, hedef kitleyle güçlü etkileşim ve tüketicilerden gelen gerçek zamanlı yanıtlar, influencer pazarlamanın popülaritesini arttırmaktadır (Chopra vd., 2020: 2). 2018 yılında, 137 milyon \$ değerinde olan küresel influencer pazarlama platformu pazarının, 2020'de 162 milyon \$'a çıkması ve 2027'de 370 milyon \$'ı aşması beklenmektedir (Guttmann, 2020a). Sosyal ağlar aracılığıyla hali hazırda bağlı olan dünya çapında 3,6 milyar insanla, sosyal medya pazarı da hızla büyümekte ve her yıl pazara yeni uygulamalar girmektedir. İşletmelerin reklamcılık faaliyetlerini arttırmak için sosyal ağları giderek daha fazla kullanması influencer pazarlama trendiyle sonuçlanmıştır (Johnson, 2020). YouTube influencer pazarındaki küresel harcamaları araştıran bir rapor, sponsorlu bağlantılara sahip 2,5 milyon video içeren 149 milyondan fazla YouTube videosunu analiz etmiştir. Trend, influencer pazarlama harcamalarının dünya çapında 513 milyon \$’a ulaştığ 1 kasım ayında 2019 yılı için büyüyen bir pazar büyüklüğünü göstermektedir (Guttmann, 2020b).

Bununla birlikte influencer'lar ile çalışan Danimarkalı işletmeler, son yıllarda gelirlerinin arttığını görmüştür. 2016 yılı itibarıyla 49 milyon Danimarka Kronundan başlayan işletme gelirleri, 2018'in üçüncü çeyreği ile 2019'un ikinci çeyreği arasında 115 milyon Danimarka Kronuna ulaşmıştır (Tankovska, 2020). Association of National Advertisers, 2018 yılı itibariyle işletmelerin \%75'inin influencer pazarlamayı kullandığını ve \%43'ünün 12 ay içerisinde harcamalarını artırmayı planladığını bildirmektedir (https://www.ana.net/ , 2018). Öte yandan, fenomen (örn. Yağcl, 2018) ya da nüfuz (örn. Şahin, 2019) pazarlama olarak da 
kullanılabilen influencer pazarlamaya literatürde de artan bir ilgi vardır. Tablo 1, yakın dönemde influencer pazarlama alanında yapılan araştırmalar ve elde edilen bulguların bir özetini sunmaktadır.

Tablo 1: Influencer Pazarlama Literatürü

\begin{tabular}{|c|c|}
\hline Yazar(lar) & Araştırma Bulguları \\
\hline Nadanyiova vd., 2020 & $\begin{array}{l}\text { Bulgular, influencer pazarlamanın Slovak tüketici yaşam tarzları (özellikle } 35 \\
\text { yaşın altındaki) üzerinde önemli bir etkiye sahip olduğunu göstermektedir }\end{array}$ \\
\hline Zak ve Hasprova, 2020 & $\begin{array}{l}\text { Bulgular, bazı ürünlerin influencer'lar aracılığıla tanıtılmasının diğerlerinden } \\
\text { daha avantajlı olabileceğini göstermiştir. Giysi, ayakkabı, kozmetik vb. ürünler ve } \\
\text { hizmet satın alımında influencer'lar en büyük etkiye sahiptir ancak yiyecek, } \\
\text { mücevher ve elektronik satın alımında da influencer pazarlamanın rolü göz ardı } \\
\text { edilmemelidir }\end{array}$ \\
\hline Yodi vd., 2020 & $\begin{array}{l}\text { Bulgular, influencer pazarlamanın, tüketici davranışı yoluyla satın alma } \\
\text { kararlarına önemli katkı sağladığını göstermektedir }\end{array}$ \\
\hline Chetioui vd., 2020 & $\begin{array}{l}\text { Bulgular, moda influencer'larına yönelik tutumların marka tutumunu ve } \\
\text { tüketicinin satın alma niyetini olumlu yönde etkilediğini göstermektedir. Ayrıca } \\
\text { bulgular, algılanan güvenilirlik, güven, algılanan davranışsal kontrol, algılanan } \\
\text { öznel normlar, algılanan uzmanlık ve algılanan uyumun, moda influencer'larına } \\
\text { yönelik tutumları olumlu yönde etkilediğini de göstermektedir }\end{array}$ \\
\hline Lee ve Kim, 2020 & $\begin{array}{l}\text { Bulgular, Instagram gönderilerinde yer alan son derece güvenilir markaların } \\
\text { mesaj güvenilirliği, reklama yönelik tutum, satın alma niyeti ve elektronik ağızdan } \\
\text { ağıza pazarlama niyeti üzerinde olumlu bir etkisi olduğunu ortaya koymaktadır }\end{array}$ \\
\hline Trivedi ve Sama, 2020 & $\begin{array}{l}\text { Bulgular, tüketici elektroniği ürünlerinin pazarlama iletişimlerini planlarken, } \\
\text { çekici bir ünlü (celebrity) influencer'a göre uzman bir influencer seçilmesinin } \\
\text { kesin bir avantaj olduğunu ortaya koymaktadır }\end{array}$ \\
\hline $\begin{array}{l}\text { Femenia-Serra ve } \\
\text { Gretzel, } 2020\end{array}$ & $\begin{array}{l}\text { Bulgular, influencer pazarlamanın destinasyon yönetim organizasyonlarına, } \\
\text { sosyal medya tabanlı elektronik ağızdan ağıa pazarlamanın gücünden tam olarak } \\
\text { yararlanırken, markalaşma ve bir destinasyonu tanıtma üzerinde yeniden kontrol } \\
\text { kazanma fırsatı sağladığını ortaya koymaktadır }\end{array}$ \\
\hline $\begin{array}{l}\text { Theocharis ve } \\
\text { Papaioannou, } 2020\end{array}$ & $\begin{array}{l}\text { Bulgular, mega etkileyicilerin en çekici, makro etkileyicilerin son derece } \\
\text { uzmanlaşmış ve mikro etkileyicilerin ise en güvenilir ve gerçek olarak kabul } \\
\text { edildiğini göstermektedir }\end{array}$ \\
\hline Canöz vd., 2020 & $\begin{array}{l}\text { Bulgular, tüketicilerin çoğunlukla sosyal medya fenomenlerini takip ettiklerini ve } \\
\text { influencer pazarlamayı etkili bir yöntem olarak bulduklarını göstermektedir }\end{array}$ \\
\hline Çetin ve Öziç, 2020 & $\begin{array}{l}\text { Bulgular, katılımcıların satın alma aşamasında fenomenlerden etkilendiği ve } \\
\text { katılımcıların fenomen pazarlamasını gerekli bulduğunu göstermektedir }\end{array}$ \\
\hline Dogra, 2019 & $\begin{array}{l}\text { Bulgular, influencer pazarlamanın kozmetik markalarının marka bağlılığ } \\
\text { üzerinde etkisi olduğunu ancak hem Z hem de Y Kuşağı üzerindeki etkisinde bir } \\
\text { fark olmadığını göstermektedir }\end{array}$ \\
\hline Jin vd., 2019 & $\begin{array}{l}\text { Bulgular, Instagram ünlülerinin marka gönderilerine maruz kalan tüketicilerin } \\
\text { kaynağı daha güvenilir olarak algıladıklarını ve onaylanan markaya karşı daha } \\
\text { olumlu bir tutum sergilediklerini göstermektedir }\end{array}$ \\
\hline Lou ve Yuan, 2019 & $\begin{array}{l}\text { Bulgular, influencer'ın oluşturduğu içeriğin bilgilendirici değerinin, influencer'ın } \\
\text { güvenilirliğinin, çekiciliğinin ve takipçilere olan benzerliğinin, takipçilerin } \\
\text { influencer'ın markalı yayınlarına olan güvenini olumlu yönde etkilediğini; bu } \\
\text { durumun da marka farkındalığını ve satın alma niyetlerini etkilediğini } \\
\text { göstermektedir }\end{array}$ \\
\hline Childers vd., 2019 & $\begin{array}{l}\text { Bulgular, milyar dolarlık influencer pazarlama endüstrisinin, stratejik karar } \\
\text { vermeyi etkileyen ve etkili uygulanması için işletme sürecinde değişiklikler } \\
\text { gerektiren büyük ölçüde keşfedilmemiş bir bölge olduğunu göstermektedir }\end{array}$ \\
\hline Coates vd., 2019 & $\begin{array}{l}\text { Bulgular, influencer pazarlamanın alternatif bir markaya göre çocukların tanıtılan } \\
\text { atıştırmalıkları hemen alımını arttırdığını göstermektedir. Ayrıca, reklam } \\
\text { açıklamaları etkiyi artırabilir }\end{array}$ \\
\hline
\end{tabular}


Tablo 1. Devam1

\begin{tabular}{|c|c|}
\hline Bognar vd., 2019 & $\begin{array}{l}\text { Bulgular, influencer ile tüketicinin ürün üzerindeki algısı arasında pozitif bir ilişki } \\
\text { olduğunu ve dolayısıyla tüketicilerin, influencer'ın tavsiyelerine önemli ölçüde } \\
\text { tepki gösterdiğini ortaya koymaktadır }\end{array}$ \\
\hline Mumbengegwi, 2019 & $\begin{array}{l}\text { Bulgular, influencer pazarlamanın tüketici temelli marka değeri üzerinde olumlu } \\
\text { bir etkiye sahip olduğunu ve influencer pazarlama ile tüketicilerin markayı tanıtıcı } \\
\text { içeriği sosyal medyada yayınlama istekliliği arasındaki önemli korelasyonlar } \\
\text { olduğunu göstermektedir }\end{array}$ \\
\hline $\begin{array}{l}\text { Kadekova ve } \\
\text { Holiencinova, } 2018\end{array}$ & $\begin{array}{l}\text { Bulgular, influencer'ların } \mathrm{Y} \text { ve } \mathrm{Z} \text { Kuşaklarının tüketici davranışları arasında } \\
\text { önemli farklılıklar olduğunu göstermektedir ve bu da farklı pazarlama fırsatlarına } \\
\text { yol açmaktadır }\end{array}$ \\
\hline Grafström vd., 2018 & $\begin{array}{l}\text { Bulgular, influencer tarafından sunulan promosyonlar, mesajların güvenilirlik } \\
\text { derecesi ve influencer tarzındaki değişiklik gibi çeşitli nedenlerden dolayı Y } \\
\text { kuşağının tutumlarının influencer pazarlamasından etkilendiğini göstermektedir }\end{array}$ \\
\hline Zhang vd., 2018 & $\begin{array}{l}\text { Bulgular, çevrimiçi influencer onaylarının satışlar üzerinde olumlu etki } \\
\text { gösterdiğini ve çevrimiçi onay etkisinin daha fazla takipçisi olan influencer'lar için } \\
\text { daha güçlü olduğunu görtermektedir. Ayrıca, ürünleri sıklıkla onaylamanın } \\
\text { çevrimiçi influencer destek çabalarına ters etki yaptığına dair kanıtlar } \\
\text { bulunmuştur. }\end{array}$ \\
\hline Glucksman, 2017 & $\begin{array}{l}\text { Bulgular, halkla ilişkiler girişimlerinde sosyal medya influencer pazarlaması } \\
\text { kullanımının tüketici ile marka arasındaki duvarı yıktığını ve ikisi arasındaki } \\
\text { etkileşim şeklini değiştirdiğini ortaya koymuştur }\end{array}$ \\
\hline Chatzigeorgiou, 2017 & $\begin{array}{l}\text { Bulgular, influencer pazarlamanın, potansiyel bir destinasyon olarak kırsal bir } \\
\text { turizm alanını seçerken } \mathrm{Y} \text { kuşağının karar verme sürecini etkilediğini } \\
\text { göstermektedir }\end{array}$ \\
\hline Byrne vd., 2017 & $\begin{array}{l}\text { Influencer pazarlama, halk sağlığında temel bir rol oynar; katılımcılarının \% } 59 \text { 'u } \\
\text { sosyal medya platformlarında sosyal influencer'ları takip etmiş ve \% } 16 \text { 'sı } \\
\text { influencer'ların yiyecek seçimlerini belirlemede yüksek etkiye sahip olduğunu } \\
\text { bildirmiştir. Ayrıca katılımcıların \%32'si sosyal influencer'ların kendilerini daha } \\
\text { sağlıklı gıda seçimleri yapmaya motive ettiğini iletmiştir }\end{array}$ \\
\hline
\end{tabular}

$\mathrm{Bu}$ çalışma, güncel istatistikleri de paylaşarak influencer pazarlamayla ilgili geniş bir kavramsal çerçeve oluşturmaya odaklanmaktadır. Ayrıca çalışma, influencer pazarlama stratejilerinden de bahsederek ilgili kararları alırken işletme yöneticilerine ve pazarlamacılara yardımcı olmayı amaçlamaktadır. Bu amaçla öncelikle influencer kavramı ve türleri anlatılmış, ardından influencer pazarlama kavramı, influencer pazarlama ile ağızdan ağıza ve elektronik ağızdan ağıza pazarlama ilişkisi incelendikten sonra çalışma, influencer pazarlamanın avantajları, influencer pazarlamada karşılaşılan zorluklar ve influencer pazarlama stratejileri açıklanarak sonlandırılmıştır.

\section{INFLUENCER'LARIN YÜKSELIŞİ}

Katz ve Lazarsfeld (1955) kanaat önderlerini, yakın çevrelerindeki diğer kişileri etkileme olasılığı olan bireyler olarak tanımlar. Kanaat önderleri, hem kaynak hem de rehber olarak hareket eden, bilginin yayılmasında etkili ve kritik bir rol oynayan geniş bir sosyal ağa sahip bireylerdir ve sahip oldukları etki, güç veya prestije değil, akranlarını siyasette, toplumda ve tüketici tercihleri arasında neyin önemli olduğu konusunda bilgilendiren iletişim kaynağ1 olarak hizmet etme yeteneklerine dayanmaktadır (Stubb, 2019: 12). 1955'te Elihu Katz ve Paul F. Lazarsfeld, önceki medya düşüncelerinden radikal bir şekilde ayrılan medya etkilerini anlamak için iki aşamalı iletişim akışı kavramını sunmuştur. Medyadan kitle izleyicilerine doğrudan bir bilgi (ve etki) akışı olduğunu varsayan önceki kavramların 
aksine, iki aşamalı akış kavramı, medyadan kanaat önderlerine ve onlardan sosyal ağlarındaki diğer insanlara (birincil grup) bilgi ve fikir hareketini içermektedir (Hirokawa ve Lowe, 2002: 3).

Bununla birlikte, günümüzün dijital toplumunda, fiziksel mevcudiyet artık kişisel etkileşimin tek belirleyicisi değildir; bu durumu, coğrafi alan yerine internet aracılı̆̆ıyla yakından bağlantılı çevrimiçi topluluklar almıştır (Stubb, 2019: 12). Son yıllarda, dijital dünyadaki ve çevrimiçi platformlardaki yeni tür ünlüler, aynı zamanda influencer'lar veya ünlü onaylayıcılar olarak da bilinen bloggerlar, vlogger'lar ve instafamous insanlar gibi popülerlik kazanmıştır (Claesson ve Ljungberg, 2018: 22). Geleneksel yüz yüze fikir liderleriyle karşılaştırıldığında, dijital influencer'lar sosyal ağları aracılığıyla daha geniş bir erişim sunar ve ağızdan ağıza pazarlamanın güçlü uyarıcılarıdır (Braatz, 2017: 6).

Influencer'lar, gerçek veya algılanan yetkileri, bilgileri, konumları ve ilişkileri nedeniyle başkalarının satın alma kararını etkileme gücüne sahip kişiler ve aynı zamanda marka savunucuları ve niş destekçileridir (Influencer Marketing, 2020). Farmer (2017)'e göre influencer'lar, bilgi, beceri ve karakterlerine göre, meslektaşlarının tutumlarını (aynı veya alt pozisyonda ve hatta bazen yöneticilerde) etkileyebilen kişilerdir yani influencer'lar organizasyon içinde kararlar vericiler de olabilir. Bu nedenle, influencer'ın mutlaka sosyal ağlar üzerinde etkili kişi olması gerekmez. Ancak günümüzde, influencer terimi genellikle sosyal medya influencer'ları için kullanılan bir terimdir (Bognar vd., 2019: 304).

Sosyal medya influencer'ları, bloglar, tweetler ve diğer sosyal medya kanallarının kullanımı yoluyla bir kitlenin tutumlarını şekillendiren yeni bir bağımsız ve üçüncü taraf destekçiyi temsil eder. Instagram, YouTube, Twitter ve Facebook gibi siteler aracılığıyla sosyal medya influencer'ları, takipçi ve marka bilinirliği elde etmek amacıyla belirli markaları tanıtan içerikler oluşturur (Glucksman, 2017: 78). Instagram'da influencer pazarlamanın popülaritesi hızla artmaktadır. Küresel pazarın, 2018'de 1,3 milyar \$'dan, 2020'de yaklaşık 2,6 milyar \$'a çıması ve marka sponsorlu influencer paylaşımlarının sayısının da 2020'de altı milyarı geçmesi beklenmektedir (Guttmann, 2020c).

Sosyal medya ünlüleri, film, müzik ve TV şovlarıyla ünlü olan geleneksel ünlülerin aksine, sosyal medyadaki varlığıyla ünlenen bireyleri ifade eder. Bu yeni tip ünlülerin etkilerini incelerken, tüketicilerin kendilerine karşı daha güçlü bir bağlılığa sahip oldukları ve onları daha özgün olarak algıladıkları görülmüştür. Bu geleneksel olmayan yıldızların algılanan gerçekliği ve derin bağlılık, destekledikleri ürünlerin daha yüksek satın alma niyetiyle sonuçlanır çünkü tüketiciler onları kendileriyle özdeşleştirir ve taklit etmeye çalışır (Jin, Muqaddam ve Ryu, 2019: 3). Global Web Index'in Ağustos 2019'da yaptığı bir anket, ABD ve İngiltere'den yanıt verenlerin \% 17'sinin bir önceki ay sosyal medyadaki bir influencer veya ünlü gönderisinden esinlenerek bir satın alma işlemi gerçekleştirdiğini ortaya koymuştur (Williamson, 2020). Benzer şekilde Einarsdottir (2017) çalışmasında, Influencer ile takipçi arasında oluşan samimiyet ve güvenilirliğin reklamları daha etkili hale getirdiğini ve katılımcların, bir ünlüden ziyade sosyal medya influencer'ından ürün veya hizmet satın alma olasılıklarının daha yüksek olduğunu bulmuştur (Einarsdottir, 2017).

Öte yandan etki, geniş anlamda bir kişiyi, herhangi bir şeyi veya olayların seyrini etkileme gücü olarak tanımlanabilir (Biaudet, 2017: 11) ve üç bileşenden oluşur: Alaka düzeyi, erişim, rezonans. Alakalı bir influencer, işletme ve sektörüyle ilgili içerik paylaşır. Hedef pazarıyla 
uyumlu bir kitleye sahip olması gerekir. Erişim, influencer'ın takipçi tabanı aracılığıyla işletmenin potansiyel olarak ulaşabileceği kişi sayısıdır. Rezonans, influencer'ın markayla alakalı bir kitleyle oluşturabileceği potansiyel etkileşim düzeyidir. Influencer'lar, marka ile tüketici arasında nihai bağlantı görevi görür; tüketicilere karşı dürüstlükleri ve açıklıkları sayesinde, yüksek sosyal nüfuz ve güvenilirliğe sahiptir ve bu da onları başarılı kılan noktadır. Ancak influencer pazarlama yalnızca çok sayıda insana ulaşmaktan ibaret değildir; doğru kişilere ulaşmakla ilgilidir. İçeriğin doğru kişilere ulaşması, çoğu kişiye ulaşmasından daha önemlidir. Newberry (2019), daha büyük takipçi sayısının her zaman daha iyi olmadığını, işletmenin faaliyet alanına göre, mikro influencer'ların çok daha adanmış ve bağlı takipçileri olabileceğini belirtmektedir (Newberry, 2019; Shewan, 2017). Benzer şekilde Glucksman (2017), geleneksel pazarlamanın çoğunlukla kitleleri hedeflediği yerlerde, influencer'ların daha önce ulaşılamayan niş kitleleri hedefleme konusunda benzersiz bir yeteneğe sahip olduğunu vurgulamaktadır (Glucksman, 2017: 78).

Solis, etkiyi belirleyen önemli ölçütler olarak web sitesi trafiği, bloga giden bağlantıları, abone sayısını ve temsil ettikleri sektörü kavrama derecelerini vurgular. (Solis, 2008: 5). Inkybee (2016), en önemli etki ölçütlerini, izleyici boyutu, yayın sıklığı, katılım düzeyi ve arama motoru optimizasyonuna dayalı ölçütler olarak sıralarken, Hearn ve Schoenhoff (2016) markayla uyuma dikkat çeker (Gretzel, 2018: 2). Krasniak ise, özgünlüğü ve dürüst marka incelemesini etki için en önemli faktörler olarak öne çıarmaktadır (Krasniak, 2016). Günümüzde tüketiciler, bilinçli bir karar vermek için diğer tüketicilerin ve influencer'ların fikirlerini almayı tercih etmektedir. Bu nedenle, influencer'lar artık bir markanın ürün veya hizmetleri hakkında tüketici görüşleri oluşturmada önemli bir rol oynamaktadır. Öte yandan Influencer'lar, müşteri kazanımı ve marka katılımı için kullanılırken, doğru marka mesajını teşvik ederek belirli bir hedef grup üzerinde en güçlü etkiye sahip olacak doğru influencer türünü belirlemek bir zorluk olmaya devam etmektedir (Chopra vd., 2020: 2).

\subsection{Influencer Türleri}

Influencer'lar, ünlülerin aksine her yerde ve herhangi biri olabilir. İnsanların sorularına cevap veren ve kendi uzmanlık alanlarında en ilgi çekici sosyal paylaşımları yapan kişilerdir. En iyi resimleri paylaşır, en eğlenceli videoları hazırlar, en bilgilendirici çevrimiçi tartışmaları yürütür (https://influencermarketinghub.com/ ,2020a) ve geniş bir etki yelpazesine sahiptir. Araştırma firması L2, Ekim 2017 Micro vs Mega Influencer Raporu'nda mikrodan ünlüye kadar değişen altı etki kademesini tanımlamıştır (5.000'den az takipçisi olan içerik oluşturucular dâhil edilmemiştir). Buna göre, 5000 ile 25.000 takipçisi olanlar mikro; 25.000 ile 100.000 takipçi arası küçük; 100.000-250.000 takipçi arası orta; 250.000 ile 1 milyon takipçi arası geniş; 1 milyon ile 7 milyon takipçi arası mega; 7 milyon ve üzeri ise ünlü influencer olarak adlandırılmıştır (Cruz, 2018).

Benzer şekilde Campbell ve Farrell, influencer'ları, nano (0-10.000 takipçi); mikro (10.000100.000 takipçi); makro (100.000-1 milyon takipçi); mega (1 milyon ve üzeri); ünlü (1 milyon ve üzeri) influencer'lar olmak üzere beş grupta incelemiştir. Ünlü (celebrity) influencer'lardan farklı olarak mega influencerlar, sosyal medyada olmadan önce ünlü statüsünden yoksun kişilerdir. İnternette ünlü olsalar da, tipik olarak takipçi grupları dişında görece bilinmeyenlerdir (Campbell ve Farrell, 2020: 3). ABD'de 2019'un başlarında 719 katılımciyla yapılan bir ankete göre, ortalama olarak, endüstri profesyonelleri mikro 
influencer'lar ile ortaklık için 32.000 \$ harcamaya istekliyken, bu oran influencer ünlülerin de yer aldığ kampanyalarda yaklaşık 39.000 \$'dir (Guttmann, 2020d).

Sudha ve Sheena (2017), influencer türlerini, geleneksel, djital, bağlantı sayısına göre ve konuya göre influencer'lar olarak gruplandırmaktadır (Sudha ve Sheena, 2017: 16-17). Öte yandan Gross ve Von Wangenheim (2018), influencer'ları dört farklı türde incelemektedir. Influencer türleri, influencer'ın birden çok alanda içerik yaratma derecesi olarak tanımlanan etki alanı genişliği ve desteklediği kitle iletişiminin yoğunluğu olarak tanımlanan sosyal mevcudiyet ile daha da ayırt edilebilir. Ayrıca influencer türleri, izleyici geri bildirimlerine göre zaman içinde gelişebilir. (Gross ve Von Wangenheim , 2018: 32- 34):

- Kaşifler (Snoopers): Sosyal medya platformlarının kaşifleridir. Eğlenceyle motive olurlar; içerik oluşturmaktan ve paylaşmaktan zevk alırlar. İçerik oluşturmak, benzer düşünen bir kitleyle paylaşmaktan hoşlandıkları hobileri veya tutkusudur. Sosyal medyada içerik oluşturmalarının nedenleri, kendini ifade etme, başkalarıyla paylaşma ve deneyimleme, sosyal arkadaşlık ve iletişim ağı oluşturmadır.

- Bilgilendiriciler (Informers): Bilgilerini paylaşmayı, böylece sosyal medyada alanlarıyla ilgili önemli boşluklarını doldurmayı hedefler. Kaşiflerin aksine, bilgilendiricilerin motivasyonları, aranan bilgilendirici, eğitici ve destekleyici içerik sağlamaktır. Yüksek derecede yetkinlikleri, uzmanlıkları ve alan bilgileriyle katkıda bulunur. Hedef kitleleri, alana özgü sorunları ele alırken tavsiye ve yardım ister. Bilgilendiriciler, içerikleriyle takipçilerinin ihtiyaçlarını, merakını ve ilgi alanlarını tatmin eder.

- Eğlendiriciler (Entertainers): Eğlenceli içerikler oluşturarak izleyicilerine eğlence, keyif ve rahatlama sağlar. Eğlenceli içerikler müzik, tiyatro, oyunculuk, korku veya komedilerden oluşur. İçerik, influencer'ın yaratıcılığına, yenilikçiliğine ve vizyonuna göre değişir. Eğlendiriciler, takipçilerinin iyi vakit geçirmesini sağlar ve genellikle içeriklerine kişisel bir dokunuş, bağlantı ve iç görü katar.

- Infotainers: Informers ve Entertainers'in karma bir versiyonudur. Bu tür influencer'lar kendi alanlarında iyi okumuş uzmanlardır. Bununla birlikte, alanla ilgili konular, içeriğin daha yüksek oranda eğlenceli unsurlar içermesi açısından ikincildir. İçerikleri, eğlenceli konular, video blogları (örn. vlog'lar) gibi kişiselleştirilmiş ve duygusal öğeler içerir. Yine de eğlence her zaman odak alanlarına bağlı kalır. Alanla ilgili konuların daha fazla eğlence ile ilgili konuya oranı, influencer'a bağlıdır.

\section{INFLUENCER PAZARLAMA KAVRAMI}

Dijitalleşme ve internetin son yıllarda buna eşlik eden yükselişi nedeniyle, giderek daha fazla insan birbirleriyle iletişim kurmak için sosyal medyayı kullanmaktadır (Tabellion ve Esch, 2019: 1). 2020'de dünya çapında 3,6 milyardan fazla olan sosyal medyayı kullanıcıların, 2025 'te yaklaşık 4,41 milyara çıkması beklenmektedir (Clement, 2020). Sosyal medyanın çoğalan kullanımı ve sosyal medya platformları aracılığıyla iletilen bilginin de artması, tüketici davranışında elektronik ağızdan ağıza (eWOM) ilginin yüksek olmasına yol açmaktadır. Bu eğilim, bilinen kişilerin önerileri ve çevrimiçi yayınlanan tüketici görüşleri, 
tüketicilerin kararları ve satın alma davranışları için çok güvenilir kaynaklar olarak güçlendirilmiştir (Tabellion ve Esch , 2019: 1).

Influencer pazarlama, işletmeler tarafından giderek daha fazla benimsenen yeni bir stratejidir. Şekil 1, dünya çapındaki işletmeler için reklam medyası karmasının nasıl değiştiğini göstermektedir. Martinez-Lopez vd. (2020)'göre influencer pazarlama, sosyal platformlarda çok sayıda takipçisi olan etkili fikir liderlerinin (influencer), ünlülerin veya ünlü olmayanların, bu platformlardaki paylaşımları kullanarak takipçilerinde (tüketiciler) markanın çıkarlarına ilişkin olumlu tutum ve tepkileri teşvik etmesi olarak tanımlanabilir (Martinez-Lopez vd., 2020: 1; Global Influencer Marketing Report, 2019 ). Wong'a (2014) göre influencer pazarlama, genel anlamda potansiyel alıcılar üzerinde etkisi olan kişileri belirleyen ve hedefleyen bir pazarlama formu olarak tanımlanabilir. Ancak bir etkiye sahip olmak, çok sayıda takipçiye sahip olmaktan daha fazlasıdır; influencer ile takipçileri arasındaki ilişki, influencer'ın uzmanlığı ve güvenilirliğiyle ilgilidir (Isosuo, 2016: 13).

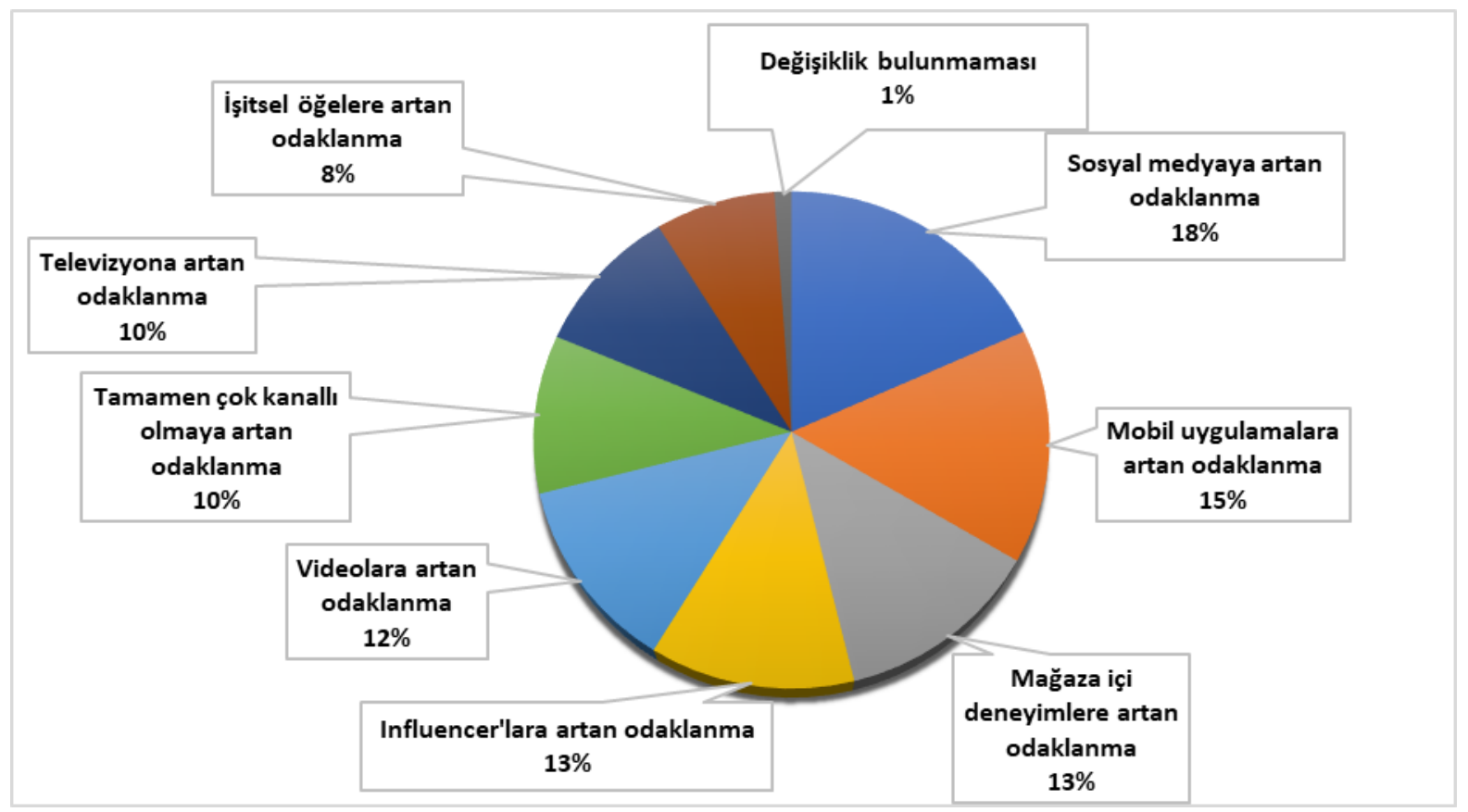

Şekil 1. İşletmelerin Reklam Medya Karması Değişiklikleri

Kaynak: (Global Influencer Marketing Report, 2019)

Bognar vd. (2019), influencer pazarlamayı, belirli bir eğilimin mesajını ve hedeflenen kitlesini sponsorlu içerik şeklinde yaymak için internet üzerinde etkisi olan insanları meşgul etme davranışı ve bilimi olarak tanımlamaktadır (Bognar vd., 2019: 305). Influencer pazarlama, ağızdan ağza pazarlamanın dijital eşdeğeridir. Byrne vd. (2017) influencer pazarlamayı, bir markanın mesajını daha büyük pazara yönlendirmek için kilit liderleri kullanmaya odaklanan bir pazarlama türü olarak tanımlamaktadır (Byrne vd., 2017: 1). Influencer pazarlama, tüketicilerin satın alma tercihlerini etkileyen harici bir kişinin eylemidir ve bir markanın mesajını tanıtma amacıyla hedef kitleye ulaşmak için dijital medyayı takip eden bir kitleyi yöneten influencer'lara odaklanır. (Chopra vd., 2020: 3). Influencer pazarlama, işletmenin sektöründe otoritesini, güvenilirliğini ve düşünce liderliğini göstermekle ilgilidir (https://influencermarketinghub.com/ , 2020a). 
Sudha ve Sheena (2017), influencer pazarlamayı, bir markanın artan erişim, satış veya katılım kampanyasının bir parçası olmak için belirli bir hedef kitle veya ortam üzerinde etkisi olan bireyleri belirleme ve harekete geçirme süreci olarak tanımlamaktadır. Narassiguin ve Sargent (2019), influencer pazarlamayı, pazarlama faaliyetlerinin sosyal medyada etkili bir kişi etrafında şekillendiği bir pazarlama alt alanı olarak tanımlar. Influencer pazarlama, sosyal bir bağlama odaklanan ve daha profesyonel bir şekilde gerçekleştirilen ağızdan ağıza pazarlama konseptinin bir uzantısıdır. Influencer pazarlama, hedef kitlelerini genişletmek ve güven ve özgünlük yoluyla sadık müşterilere dönüştürmek isteyen markalar için çok faydalı olabilecek bir ilişki kurma biçimidir ve iki tür influencer pazarlama olduğundan bahsedilmektedir (Sudha ve Sheena, 2017: 16; Narassiguin ve Sargent, 2019: 1):

* Kazanılan influencer pazarlama: Influencer tarafından kendi kişisel sosyal gelişimini ilerletmek için teşvik edilen influencer'larla veya üçüncü taraf içeriğiyle ücretsiz veya önceden var olan ilişkilerden kaynaklanır.

* Ücretli influencer pazarlama: Ücretli influencer pazarlama kampanyaları sponsorluk, videodan önce gösterilen reklam veya referans mesajı şeklinde olabilir ve içeriğin herhangi bir noktasında görünebilir.

Association of National Advertisers'in 2018 yılı anketine göre, markaların \%62'si influencer'lar ile para karşıllı̆̆ anlaşırken, \%35'i influencer hizmetleri karşılığında ücretsiz ürün sağlamakta ve \%30, her bir gönderi için ücret vermektedir. Markalarının influencer'larının ne kadar ücret aldığını bilen ankete katılanların \%62'si yıllık 100 bin \$'ın altında ve \%38'i 100 bin doların üzerinde harcama yapıldığını belirtmiştir (https://www.ana.net/ , 2018). MediaKix'in 2019 Influencer Pazarlama anketine göre, influencer pazarlama bütçeleri, işletmenin büyüklügüne bağlı olarak değişebilmektedir. Ankete katılanların \%15'i 0-1000 \$, \%19'u 1001-10 bin \$, \%17'si 10001-50 bin \$, \%14'ü 50001100 bin $\$, \% 18^{\prime}$ i $100001-500$ bin $\$, \% 10^{\prime}$ u 500001-100 bin $\$$ aras1 ve $\% 7^{\prime}$ si ise 1 milyon \$'1n üzerinde influencer pazarlama bütçesi ayırdıklarını iletmiştir (https://mediakix.com/ , 2019).

Patel (2017), uzmanlaşmak isteyen markaların belirli nişlere ve pazar segmentlerine hitap edebilecek mikro influenecer'lardan yararlanmayı tercih ettiğini ve takipçi sayıları ne kadar büyükse katılımın o kadar düşük olacağını belirtmektedir. 1.000 takipçisi olanlar genellikle paylaşımlarında \%8 beğeni alırken, 10 milyon takipçisi olanlarda bu oran \%1,6'tur. Maksimum etkileşim için ideal nokta, 10.000 ile 100.000 arasında takipçisi olan bir influencer bulmaktır (Patel, 2020). Radey (2015), en tanınmış blog yazarları ve ünlülerin en büyük erişime sahip olsalar da, hedef kitle üzerinde mutlaka en büyük etkiye sahip olamayabileceğini bu yüzden doğru kitleye niş hedeflemenin, yanlış kitleye kitlesel erişimden çok daha güçlü olacağını savunmaktadır. Ayrıca, gerçek etkinin takipçi meselesi olmadığını çünkü kolayca biriktirilebileceğini ve hatta sahte olabileceğini de belirtmektedir (Radey, 2015).

Benzer şekilde De Veirman vd. (2017), çok sayıda takipçisi olan influencer'larla iş birliği yapmanın, farklı ürünleri tanıtmak için en iyi pazarlama seçeneği olmayacağını çünkü bunun, markanın algılanan benzersizliğini ve dolayısıyla marka tutumunu düşüreceğini vurgulamaktadır (De Veirman vd., 2017: 1). Zietek (2016) araştırmasında, mikro influencer'lar ile çalışmanın, influencer pazarlamanın önemli bir bileşeni olduğunu bulmuştur. Bu influencer'lar, yüksek özgünlüğe sahiptir, belirli bir alanda uzmandır ve 
parasal nedenlerle motive edilemezler (Zietek, 2016: 1). Izea tarafından yapılan analize göre, influencer pazarlama maliyetleri son beş yılda yükselmiştir ve markalar, gönderilerini tanıtmak için büyük miktarlar harcamaya isteklidir. Instagram'da sponsorlu bir fotoğrafın ortalama maliyeti 2018 ile 2019 arasında \%44 artmıştır. 2015'te ortalama maliyet 381 \$ iken, 2019 'da 1.643 \$'dır. Twitter gönderisine sponsor olmanın maliyeti 2015 'te 34 \$'dan, 2019'da 422 \$'a çımıştır. YouTube, analizdeki en pahalı platformdur ve sponsorlu bir video 2019 'da ortalama 6.700 \$'dır ancak bu, ortalama 8.000 \$ 'a yaklaştığı 2017'den çok daha ucuzdur (McCarthy, 2019).

2019'da influencer pazarlamasına yatırım yapan İtalyan çokuluslu işletmeler, sürekli kampanyalara ortalama 120 bin Euro harcarken, tek seferlik girişimlere 61 bin Euro ayırmıştır. Küçük ve orta ölçekli işletmelerde bu harcamalar, sürekli kampanyalar için ortalama 61 bin Euro ve tek seferlik girişimler için 30 bin Euro'dur (Coppola, 2020). Instagram'ın influencer kampanyaları için artan popülaritesi, pazarlamacılar müşterilerinin olduğu yere gitme eğiliminde olduklarından, platformun güçlü kullanıcı büyümesiyle paralel gitmektedir (Enberg, 2018: 3). MediaKix'in 2019 Influencer Pazarlama anketine göre, pazarlamacıların $\% 89^{\prime} u$ influencer pazarlamadan gelen yatırım getirisinin diğer kanallarla karşılaştırılabilir veya daha iyi olduğunu söylerken, üçte ikisi 2019 yılında influencer pazarlama bütçelerini arttırmıştır. Ek olarak pazarlamacılar (Şekil 2), influencer pazarlama için yoğunlukla Instagram ve Youtube'u tercih etmiş, bu platformları Facebook takip etmiştir (https://mediakix.com/ , 2019). Launch Metrics'in 900'den fazla ajans, marka ve influencer'in katılımıyla gerçekteştirdiği State of Influencer Marketing Report'a göre, katılımcıların \%94'ü influencer pazarlamayı satışları arttırmada etkili bulmaktadır. Ayrıca katılımcıların \% 42.9'u mikro influencer'lar en etkileyici influencer türü olarak görmektedir (Cohen, 2020).

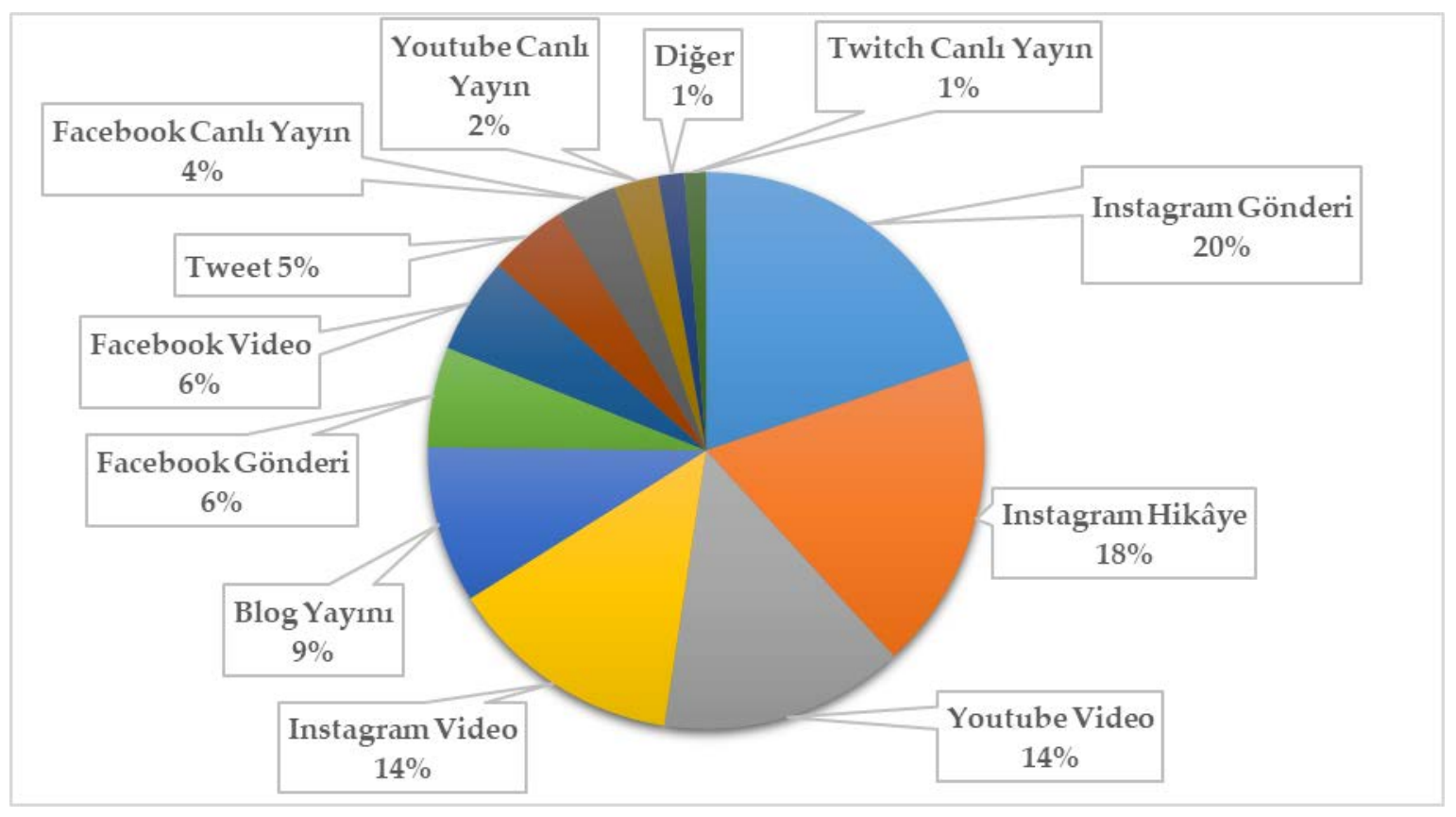

Şekil 2. En Etkili Influencer Pazarlama İçerik Formatları

Kaynak: (https://mediakix.com/,2019) 
Bununla birlikte, NeoReach'in 2020'nin üçüncü çeyreğinde (Temmuz-Eylül) 8.800'den fazla Youtube videosunu analiz ettiği Social Intelligence Insights Raporu'na göre ilgili dönemde YouTube sponsorlu videolara yapılan toplam harcama 196 milyon \$'dan fazladır. Youtube'ta reklam ve sponsorlu gönderiye en fazla harcama yapan sektörler, teknoloji, oyun, yiyecek ve içecektir. Ayrıca üçüncü çeyrekte 1,3 milyarın üzerinde sponsorlu görünüm yayınlanmıştır. $\mathrm{Bu}$, haftada 110 milyon sponsorlu görüntüleme, günde 15 milyon, saatte 600 bin, dakikada 10 bin, saniyede 170 görüntüleme anlamina gelmektedir. Dolayısılyla Youtube influencer pazarlama işletmelerin üzerinde durması gereken bir alandır (https://influencermarketinghub.com/, 2020b). Jumpshot verileri, YouTube'daki reklamlar söz konusu olduğunda, etkileyici pazarlama dönüşüm oranlarının (\% 2,7), geleneksel videodan önce ve videonun ortasında gösterilen reklam dönüşüm oranlarından $(\% 0,5)$ beş kat daha yüksek olduğunu bulmuştur. YouTube özellikle, takipçilerin belirli nişlerine hitap eden yaratıcılıkla daha uzun hikayeler anlatmak isteyen markalar için harika bir platform olarak değerlendirilebilir (Hoos, 2019).

Öte yandan influencer pazarlama ve ünlü onayı genellikle birbirinin yerine kullanılmasına rağmen aralarında farklılıklar bulunur. Influencer pazarlama, uzman olarak görüldükleri alanda güvenilen kişiler tarafından daha fazla ağızdan ağıza reklam oluştururken, ünlü onayında pazarlama yalnızca belirli ürünleri satmak için ünlülerin ününü ve itibarını kullanmaya odaklanır. Ünlü onayı söz konusu olduğunda, ünlüler içeriğin oluşturulmasında rol almaz, sadece markanın mesajını iletir ve markanın yüzü olarak kullanılır. Influencer pazarlamada influencer'lar, mesajın tamamını baştan sona kendileri oluşturur (Veissi, 2017: 10).

\subsection{Influencer Pazarlama ile Ağızdan Ağıza ve Elektronik Ağızdan Ağıza Pazarlama İlişkisi}

Ağızdan ağıza iletişim, genellikle iki kişi arasında bir bilgi alışverişi, bilgi akışı, iletişim veya konuşma olarak tanımlanır (Goyette vd., 2010: 6). Ağızdan ağıza pazarlama ise, bir marka, ürün veya hizmet hakkında ticari bir varlıkla bağlantısı olmadığı düşünülen kişiler arasında yüz yüze iletişim olarak tanımlanabilir (Meiners vd., 2010: 82). Bughin vd. (2010) çalışmasına göre, tüm satın alma kararlarının \%20 ila \%50'sinin arkasındaki ana faktör ağızdan ağıza iletişimdir. Etkisi, tüketiciler bir ürünü ilk kez satın aldıklarında, ürünler nispeten pahalı olduğunda, daha fazla araştırma yapılmasına ve daha fazla fikir aranmasına sebebiyet veren faktörler olduğunda en büyüktür (Bughin vd., 2010: 2).

İşletmeler ve pazarlamacılar, sosyal medya platformlarını yalnızca ürünler hakkındaki bilgileri müşterilere iletmek için değil, aynı zamanda ürünle ilgili bilgiler, görüşler, tutumlar ve satın alma ve satın alma sonrası deneyimler hakkında müşteriden müşteriye iletişim için bir araç olarak da kullanır (Jaakonmaki vd., 2017: 1153). Sosyal medya, akran tavsiyelerinin satın alma kararlarında daha büyük bir rol oynamasını sağlayarak, tüketiciler ve markalar arasındaki güç dengesini temelden değiştirmiştir. Twitter ve Annalect tarafından yapılan ortak bir araştırmaya göre, katıtımcıların \%56'sı arkadaşlarından gelen tavsiyelere güvendiklerini söylerken, \%49'u influencer'lara güvendiklerini belirtmiştir (Hurt, 2017: 10). Elektronik ağızdan ağıza pazarlama (eWOM), internet aracılığıyla çok sayıda kişi ve kuruma sunulan bir ürün veya şirket hakkında potansiyel, mevcut veya eski müşteriler tarafından yapılan olumlu veya olumsuz açılamalardır. Ağızdan ağıza pazarlamanın bir uzantısı olan 
influencer pazarlama, elektronik ağızdan ağıza pazarlama için güçlü bir sürücü olarak hareket edebilmektedir (Gustavsson vd., 2018: 12).

Ağızdan ağıza pazarlama (WOM), tüketicilerin kendi aralarında bir ürün veya hizmet hakkında konuşmaları, influencer pazarlama ise hedef kitlede kilit karar vericileri belirleme ve onları ağızdan ağıza pazarlamayı yaymak için etkilerini kullanmaya teşvik etme uygulaması olarak görülebilir (Jaakonmaki vd., 2017: 1153). Bununla birlikte, influencer ve ağızdan ağıza pazarlama arasında önemli farklılıklar vardır (Schaefer, 2018):

- Influencer pazarlamada, bir işletme ile ürün/hizmetle ilgili düşünceleri yaymak için belirlenen influencer arasında duygusal veya finansal bir ilişki vardır. Buna karşın ağızdan ağıza pazarlama, bir işletme ile ürünü/hizmetini yayan insanlar arasındaki ilişkilere daha az bağımlıdır.

- Ağızdan ağıza pazarlamada içerik iletimi, influencer'dan arkadaşa değil, arkadaştan arkadaşa gerçekleşir ve çoğunlukla ücretli olan influencer pazarlamaya göre, ücretsiz olarak yapilır.

- Genel olarak influencer pazarlama, bir ürünü tanıtmak için kısa vadeli hedeflere (örn. kampanya) odaklanma eğilimindedir ancak ağızdan ağıza pazarlama mesajın veya içeriğin sürekli tekrar edildiği uzun vadeli bir stratejidir.

\section{INFLUENCER PAZARLAMANIN AVANTAJLARI}

Influencer pazarlama, markanın mesajını daha büyük pazara yönlendirmek için kilit liderleri kullanmaya odaklanan bir pazarlama türüdür. İşletmeler, bir influencer'1 en temel olarak ürün yerleştirme, marka onayları ve içerik oluşturma için kullanabilmektedir. Influencer pazarlamanın başlıca faydaları, yeni müşteriler çekmek; tekrarlanan satın alımları arttırmak; müşteri sadakatini arttırmak ve müşteri yaşam boyu gelirini en üst düzeye çıkarmaktır (https://www.tapinfluence.com/ , 2015; Talkwalker, 2018: 13). Influencer pazarlama, tüketicilerin veya takipçilerin bilgiye karşı daha düşük direnç göstermesine yol açabilmektedir çünkü, influencer'lar geleneksel pazarlamadan daha yüksek özgünlüğe sahiptir (Claesson ve Ljungberg, 2018: 27). Influencer'ların pozitif bir eWOM yarattığı, bir ürüne veya markaya değer kattığı, geleneksel ve tanınmış ünlülerden daha güvenilir olduğu düşünülmektedir (Claesson \& Ljungberg, 2018, s. 23). Association of National Advertisers'in 2018 yılı anketine göre, işletmelerin \%86'sı marka bilinirliği oluşturmak için, \%69'u içerik oluşturmak ve dağıtmak için, \%56'sı marka algısını iyileştirmek için ve \%51'i satın almayı artırmak için influencer pazarlamayı kullanmaktadır (https://www.ana.net/, 2018).

Neilsen pazarlama anketine göre, influencer pazarlama, dijital pazarlamaya kıyasla 11 kat daha yüksek yatırım getirisi sağlamaktadır. Buna karşılık, ünlülerin onaylaması tüketiciler arasında marka farkındalığını artırmada daha etkili olurken, sosyal medya influencer'ları niş bir segmentle daha fazla iletişim kurabilecekleri için ürün etkileşimi ve marka sadakatini artırmada oldukça önemli bir rol oynamaktadır. İşletmeler, onaylamanın ürün bilgilerinin gerçekliğini garanti edebileceğine inanmaktadır (Lim vd., 2017: 20).

Influencer pazarlamanın daha geniş amacı, olumlu tüketici tepkileri oluşturmaktır (Ewers, 2017: 1) Keller Fay Group ve Berger tarafından 2016 yılında yapılan araştırmaya göre, tüketicilerin \%82'sinin bir mikro influencer'ın önerisini takip etme olasılığ1 yüksektir. Bu oran ortalama bir kişinin tavsiyesinde \%73'tür. Mikro influencer'ların, ortalama bir 
tüketiciye göre her hafta ürün önerilerini içeren satın alma konuşmaları 22,2 kat daha fazladır. Influencer'lar önerilerinde daha doğrudandır ve \%74'ü tüketicileri satın almaya veya denemeye teşvik eder. Influencer'lar, başkalarına sormak yerine kendi bilgilerini ilk elden alma eğilimindedir. Genel nüfusun \%26'sı, arkadaşları ve ailesi aracılığıyla markalardan haberdar olurken, influencer'ların yalnızca \%15'i marka bilgilerini bu şekilde bulmaktadır (Berger ve Keller Fay Group, 2016: 2).

Phung ve Qin, bilgi arama ve alternatiflerin değerlendirilmesi söz konusu olduğunda influencer'ların tüketiciler üzerinde en çok etkiye sahip olduğunu bulmuştur (Phung ve Qin: 2018). Influencer pazarlamanın diğer bir avantajı, markanın tüm sosyal medya hattını besleyebilen influencer içeriğinin yeniden kullanılması gibi ikincil etkilerdir. Marka sadece influencer'ların kitlelerine dağıtılmakla kalmaz; aynı zamanda iç tasarım ekiplerini kullanmaktan daha uygun maliyetlidir. Ayrıca, kampanya tamamlandığında, tüketiciler hala ürün/hizmetleri görüntüleme fırsatına sahip olacaktır ve bu da influencer pazarlama kampanyalarına devam eden bir etki sağlayacaktır (Johansen ve Guldvik, 2017: 17).

Öte yandan, reklamlar ne kadar agresif ve müdahaleci olursa, çevrimiçi kullanıcılar o kadar duyarsızlaşır, reklamları görmezden gelir ve hatta engeller. Adobe ve Pagefair'den alınan bir rapora göre, reklam engelleme yazılımı kullanımı, 2014'ün aynı dönemine kıyasla 2015'in 2. çeyreğinde \%40 ve ABD'de \%48 artmıştır. Bu, 20 milyar \$’dan fazla gelir kaybına yol açmıştır. Ancak, Influencer pazarlama, reklam engelleme yazılımlarına karşı bir tür panzehir görevi görür. Dijital izleyiciler reklamları engelleyebilir ve atlayabilir, fakat sosyal medyada takip ettikleri kişilerin içeriğini engelleyemezler (Dahan, 2016).

\section{INFLUENCER PAZARLAMADA KARŞILAŞILAN ZORLUKLAR}

Influencer pazarlamadaki en önemli adımlardan bazıları, kampanya hedeflerine karar vermek ve birlikte çalışacak doğru kişileri bulmaktır. Influencer keşfi, süreçteki en önemli ve aynı zamanda en zor noktalardan biridir (https://www.smartinsights.com/, 2018). Kampanyayı yürütmek için en uygun influencer'ları ararken, influencer'ın paylaşım yaptığı sosyal platformlar, kişilik özellikleri, etkileşim oranları, takipçilerinin hakkında ne düşündüğü, güvenilirlik düzeyi, marka sadakati çok önemlidir (Talkwalker, 2018: 17-19). Ayrıca birlikte çalışılacak influencer, markanın vizyonu, misyonu ve kimliği ile uyumlu olmalıdır (Patel, 2020). Grave (2019) araştırmasında, işletmelerin influencer pazarlama faaliyetlerini değerlendirmek için çoğunlukla etkileşim veya erişim sayısı gibi nicel, kolayca bulunabilen metriklere güvendiklerini bulmuştur (Grave, 2019: 7).

Sosyal medya influencer'larının en önemli özelliklerinden biri özgünlük, güvenilirlik ve bağımsızlıktır. Influencer'ın ürüne yönelik olumlu tutumu ile söylediği arasında bir tutarsızlık varsa, sponsorlukla ilgili etik bir sorun ortaya çıkabilir ve bu, takipçileri arasında güvenilirliğini kaybetmesine neden olabilir. Ek olarak bir gerçeklik aldatmacasının hem yasal hem de sosyal sonuçları vardır ve bir reklam doğru etiketlenmediğinde, Federal Ticaret Komisyonu (FTC) davranışı cezalandırmakla yükümlüdür (Dangl, 2017: 30-31). Lightspeed GMI ve Izea tarafından Eylül 2016'da yapılan bir çalışma, 10 ABD'li influencer'dan altısının FTC yönergelerinin farkında olduğunu veya anladığını ve pazarlamacıların \%56'sının FTC'nin politikasından haberdar olmadıklarını ortaya çıkarmıştır. Farkındalıktan bağımsız olarak, on influencer'dan üçü, sponsorlu gönderiyi veya işletmeden aldıkları ücretin açılanmamasının istendiğini bildirmiştir. Bunun nedeni, pazarlamacıların, etiketli 
gönderilerin özgünlüğünü kaybedeceğinden korkmalarıdır. Ancak, FTC yönergeleri, sosyal medyadaki sponsorlu yayınların reklam olarak etiketlenmesini gerektirir (McCarthy, 2017).

Instagram'da tüketiciler genellikle bir influencer ile bir marka arasındaki influencer pazarlamasını çeşitli şekillerde (örn. sponsorlu bir gönderi, resimlere ürün yerleştirme, bir olay veya markayla deneyim içeren bir hikâye) algilarlar (Claesson ve Ljungberg, 2018: 27). Sponsorluk açıklamasının olmaması, influencer pazarlamayla ilgili ana sorunlardan biridir çünkü sponsorluk açılanmazsa tüketiciler, influencer'ın ilgili ürünü şahsen tavsiye ettiğine inanabilir. Bu nedenle gönderilerin başına eklenen \#ad, \#sp, \#sponsored gibi etiketler görülebilir. Ancak 2014 yazında, Münih'teki bir mahkeme, \#sponsorlu etiketinin eklenmesinin bile yeterli olmadığını, çünkü bazı insanların, bunun gönderinin içeriğinin sponsor olduğu anlamına geldiğini anlamayacağını açılamıştır (Ewers, 2017: 2). Benzer şekilde Federal Ticaret Komisyonu'na göre, \#thanks, \#collab, \#sp, \#spon, or \#ambassador vb. belirsiz ifşalar, influencer pazarlamadaki yaygınlığına rağmen, influencer ile marka arasındaki maddi bağlantıyı açıklamak için yeterli değildir. Bununla birlikte, Association of National Advertisers'ın 2018 yılı anketine katılan işletmelerin \%38'i \#sponsored ve \%5'i \#ad etiketi kullanarak bir influencer gönderisinin ödendiğini ve sponsorluğunun yapıldığını iletmektedir (https://www.ana.net/, 2018). Öte yandan bir diğer sorun influencer dolandırıcılığıdır. Birçok influencer, etkilerinin olduğundan daha yaygın görünmesini sağlamak için aşağıdaki uygulamaları kullanmaktadır (Bones, 2018):

- Takipçi Satın Alma: İnternette influencer'ların belirli bir fiyat karşılığında bot takipçi satın alabileceği siteler vardır. Bu, influencer'ın takipçi sayısını arttırır ancak takipçiler gerçek değildir ve içerikle ilgilenmezler. Bu durumu anlamanın bir yolu bireysel takipçilerine göz atmaktır. Spam isimler var mı? Takipçilerin sayfalarında aktivite (resim, gönderi ve takipçi) var mı? Hesapları uzun zamandır uykuda mı? Bunlardan herhangi biri doğruysa, bu hesaplar muhtemelen influencer'ın satın aldığ 1 sahte takipçilerdir.

- İçerik çalma veya satın alma: Instagram sahte influencer'larının kullandığı bir başka yöntem, diğer kişilerin içeriklerini veya fotoğraflarını çalmaktır. Bazı influencer'lar doğrudan içeriği çalar ve ardından orijinal içeriği atıf yapmadan yayınlar.

- Etkileşim oranı ve kalitesi: Tipik olarak, sahte influencer'ların çok sayıda takipçisi vardır, ancak katılım oranları düşüktür. Influencer gönderilerinin en az 10'undaki katılım oranlarını takipçi oranları ile karşılaştırarak dengesiz bir takipçi-etkileşim oranını kolayca tespit edebilir. Gerçek kullanıcıların katılımı, genellikle yayınlanan içeriğe özgü olacaktır. Ancak bot etkileşim yanıtları spesifik değildir ve belirsiz veya genel ifadelerdir.

Ocak 2019'da Statista tarafından yapılan bir ankette, yanıt veren ABD'li pazarlamaciların \%50'si, influencer pazarlamayı kullanmanın ana zorluğunun sahte takipçileri ve gerçek olmayan katılımı tespit etmek olduğunu söylemiştir. Ankette, influencer maliyetlerinin artması pazarlamacıların \%38'i için ciddi bir sorun olarak işaretlenmiştir (Guttmann, 2020e). MediaKix'in 2019 Influencer Pazarlama anketine göre, influencer pazarlamada karşılaşılan zorluklar 11 maddede (Şekil 3) özetlenmiştir: 


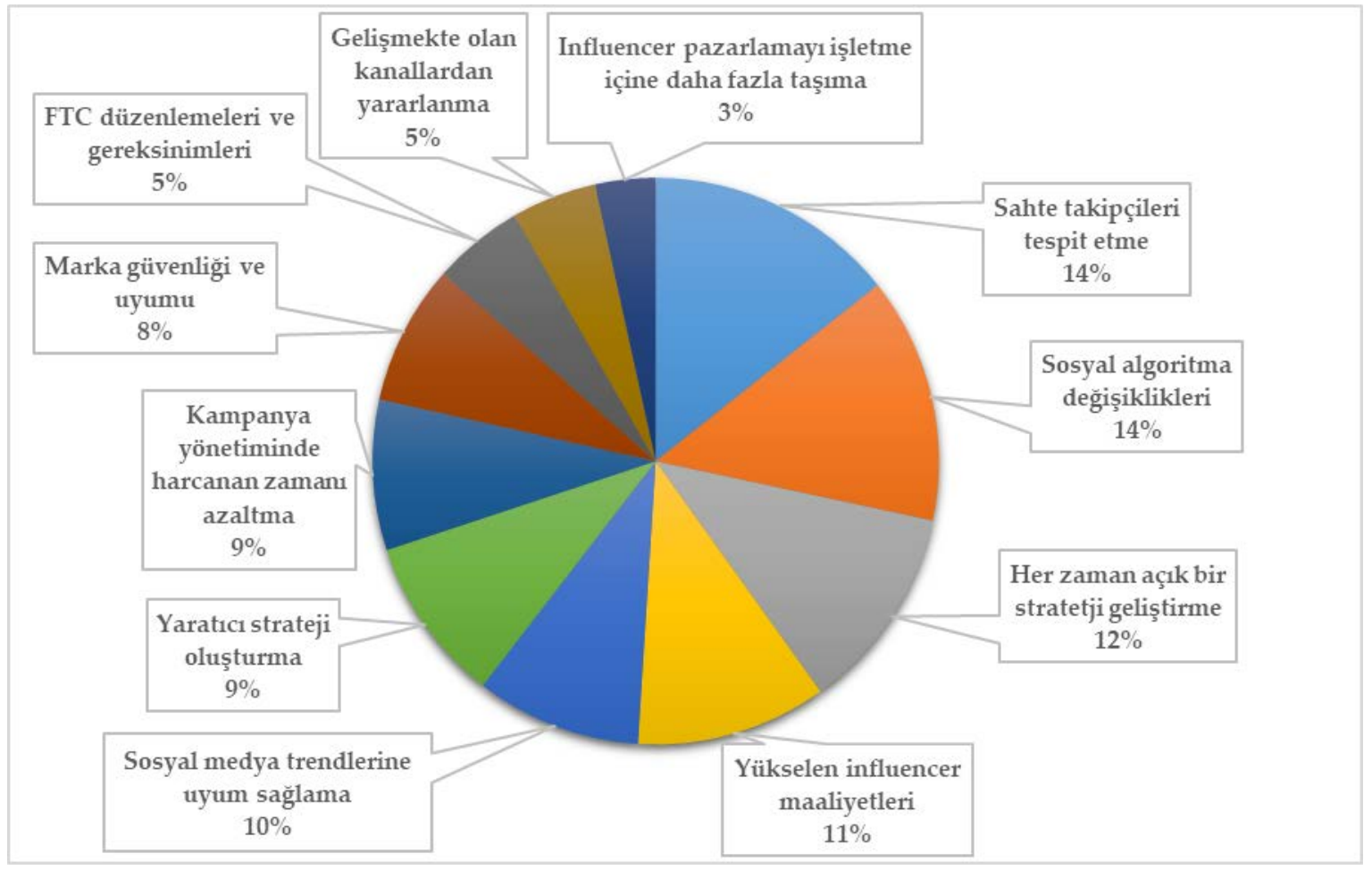

Şekil 3. Influencer Pazarlamada Karşılaşılan Zorluklar

Kaynak: (https://mediakix.com/ 2019)

\section{INFLUENCER PAZARLAMA STRATEJILERI}

Influencer pazarlama, işletmenin erişimini genişletmenin, sektördeki güvenilirliğini arttırmanın ve alanında kendini bir düşünce lideri olarak konumlandırmanın en etkili yollarından biridir. Hubspot'a göre, tüketicilerin \%71'inin sosyal medya tarafından yönlendirildiğinde satın alma olasılığı daha yüksektir ve \%92'si satın alma kararı verirken bir markaya göre influencer'a daha fazla güvenmektedir. Shewan (2017), başarılı bir influencer pazarlama kampanyasında önemli noktaları, tartışmalı bir tavra veya kışkırtıcı bir profile sahip olmamak; orijinal, erişilebilir, duyarlı ve sabırlı olmak, kendi nişini oluşturmak ve alanında uzmanların onayını almak şeklinde açıklamaktadır (Shewan, 2017; Talkwalker, 2018: 12). Başarılı bir influencer stratejisi oluşturmak, hedef odaklı olmakla ilgilidir. Patel (2020), başarılı bir influencer pazarlamasının, az çoktur ilkesine, hedef kitleye daha yakından bakmaya, onlarla sağlam ilişkiler geliştirmeye bağlı olduğunu vurgulamaktadır (Patel , 2020). Öte yandan, influencer pazarlama stratejisin temel adımları şu şekilde açılanabilir (https://influencermarketinghub.com/ , 2018):

- Hedef kitleyi tanımlamak

- Hedefleri belirlemek

- En uygun influencer'ları keşfetmek

- Fırsatları bulmak için influencer'larla birlikte çalışmak

- İçerik ve fırsat analizi yapmak

- Bir içerik planı hazırlamak 
- Alandaki ilgili konularda güncel kalmak

- Kaliteli içerik üretmek için influencer'larla iş birliği yapmak

- İçeriği dağıtmak için influencer'lar ile kampanyalar oluşturmak

- Influencer kampanyasının sonuçlarını ölçmek

MarketingProf, influencer pazarlamada başarılı olmak için; pazarlama departmanında influencer kampanyaları, bütçeleri ve ilişkileri yönetmekle görevli özel ekipler kurmak; hem işletmeler hem de tüketiciler için şeffaflık; sahte takipçiler kullanmamak; influencer'lar ile güvene dayalı ilişkiler kurarak onları marka avukatına dönüştürmek; kampanyanın etkinliğini ölçmek; doğru verileri toplamak için doğru araçlara sahip olmak ve bu verileri influencer stratejisini geliştirmek ve bilgilendirmek için kullanmak şeklinde özetlemektedir (https://www.marketingprofs.com/ , 2018). Bununla birlikte başarılı bir influencer pazarlamasında kullanılabilecek diğer statejiler aşağıdaki şekilde sıralanabilir (https://www.smartinsights.com/ ,2018):

- Bir influencer'ın gönderisini benzersiz bir kupon koduyla birleştirmek, takipçilere satın alma işlemi için ek bir dürtü sağlayabilir.

- Blog yazıları sadece bilgilendirici değil aynı zamanda satış ve marka farkındalığını da arttırır. Ayrıca daha uzun ömürlüdür.

- Sosyal medyada çok geniş bir alana ulaşan markalara atıf yapılması, işletmenin marka bilinirliğini büyük ölçüde artırabilir.

- Yarışmalar ve hediyeler, hedef kitleyi içerikle daha fazla etkileşim kurmaya teşvik eder.

- Influencer, uzun vadeli bir ortaklıkta markanın yüzü olur.

- Medya haberleri ve influencer paylaşımları, marka farkındalığını artırabilir. Etkinlikler, influencer'ların ağ kurmalarına yardımcı olarak, ilişkileri geliştirmede uygun bir yoldur.

- Influencer'ların bir markanın sosyal hesaplarına belirli bir süre erişim kazanması ve marka adına yayın yapması, ek etkileşim oluşturmak ve daha fazla takipçi kazanmak için uygun bir yoldur.

- Markalar, etkili blog yazarlarının web sitelerinde makaleler yayınlar ve bu da görünürlüğünü büyük ölçüde artırır.

- Influencer'lar arasındaki yarışmalar, bir markanın görünürlüğ̈̈nü ve katılımını büyük ölçüde artırabilir. Influencer'lar için kazanma kriterleri, sosyal paylaşımlara veya markaların web sitesinde oluşturulan trafiğe bağlı olabilir.

\section{SONUÇ}

Internet ve teknoloji alanında yaşanan gelişmelerin sonucu olarak influencer pazarlama, yakın dönemde ortaya çıkan ve işletmeler tarafından yoğunlukla kullanılmaya başlanan bir pazarlama aracıdır. Influencer pazarlama, markanın mesajını daha geniş kitlelere iletmek için dijital ortamdaki etkili kişileri kullanırken, sosyal medyada etkileşimleri arttırmak, marka bilinirliği yaratmak ve web sitesi trafiğini yükseltmeyi amaçlayan bir pazarlama 
aracıdır. Ek olarak influencer pazarlama, işletmelere daha yüksek yatırım getirisi, potansiyel müşterileri çekme, müşteri sadakatini arttırma ve satışları arttırma faydaları da sağlamaktadır.

Influencer pazarlamada kullanılan influencer'lar günlük hayatta karşılaşılan herhangi bir komşu, işletme sahibi, öğrenci, mühendis ve öğretmenden, çok ünlü bir şarkıcı ya da oyuncuya kadar çeşitlilik göstermektedir. Influencer'lar, yetkileri, bilgileri, konumları ve ilişkileri nedeniyle başkalarının satın alma kararını etkileme gücüne sahip kişilerdir ve takipçi sayılarına ve davranışlarına göre farklı gruplara ayrılabilirler. Pazarlama şirketleri tarafından yapılan anketler, tüketicilerin bir influencer'ın yönlendirmesiyle, markanın ürün/hizmetine yönelik tutumlarını değiştirdiğini göstermektedir. Burada önemli bir husus, bir influencer'ın çok sayıda takipçisi olmasının, her zaman hedef kitle üzerinde en büyük etkiye sahip olduğu anlamına gelmemesidir. Bu yüzden doğru kitleye niş hedeflemeye odaklanmak, yanlış kitleye kitlesel erişimden daha güçlü sonuçlar verebilmektedir.

Öte yandan, işletmelerin başarılı bir influencer pazarlama kampanyası yürütebilmesi için öncelikle hedef kitleyi tanımlaması, hedefleri belirlemesi, en uygun influencer'ları keşfetmesi, içerik ve fırsat analizleri yapması, kampanya boyunca influencer'larla birlikte çalışması, influencer'lar ile güvene dayalı ilişkiler kurması ve kampanyanın etkinliğini ölçmesi gerekir. Bununla birlikte, paylaşılan içeriklere indirim kuponu eklemek, yarışmalar düzenlemek ve hediyeler vermek, blog yazıları oluşturmak ve önemli markalardan onay almak da işletmelerin kullanabileceği stratejiler arasındadır. Bu noktada önemli bir detay, tüketici güvenini zedeleyen sahte takipçi satın alımı ve sahte etkileşim oranları ile başka markaların içeriğinin kopyalanması konularıdır. İşletmelerin bu tuzaklara karşı dikkatli olmasi gerekir.

Literatürde influencer pazarlama ile yapılan çalışmalar incelendiğinde, influencer pazarlama çalışmaların arttığı ancak alanın henüz tam anlamıyla keşfedilmediği görülmektedir. Influencer pazarlama ile ilgili yapılan çalışmaların bulguları, genellikle influencer pazarlamanın, tüketicilerin kaynağı daha güvenilir olarak algılamasına ve markaya karşı daha olumlu bir tutum sergilemesine yol açtığına işaret etmektedir. Influencer onaylarının satışları arttırdığına dair çok sayıda ve önemli bulgular mevcuttur. Influencer pazarlama, ayrıca işletmenin sektördeki güvenilirliğini arttırmasının ve alanında kendisini bir düşünce lideri olarak konumlandırmasının en etkili yollarından biridir. Dolayısıyla influencer pazarlama, uygun maliyetle marka mesajını, ürün ve hizmetlerini daha geniş kitlelere iletmek ve sosyal medya etkileşimini arttırmak isteyen işletmeler için tavsiye edilmektedir.

\section{KAYNAKÇA}

Berger, J. \& Keller Fay Group. (2016). Research Shows Micro-Influencers Have More Impact than Average Consumers, https://go2.experticity.com/rs/288-AZS731/images/ExperticityKellerFaySurveySummary .pdf? ga=2.222175320.1922164868.1515233850$\underline{1299873601.1515233850}$, Erişim Tarihi: 12.11.2020

Biaudet, S. (2017). Influencer Marketing as a Marketing Tool: The Process of Creating an Influencer Marketing Campaign on Instagram, Yrkeshögskolan Arcada, Thesis. 
Bognar, Z., Puljic, N. \& Kadezabek, D. (2019). Impact of Influencer Marketing on Consumer Behaviour, Economic and Social Development (Book of Proceedings), 42nd International Scientific Conference on Economic and Social Development.

Bones, B. (2018). How to Spot Authentic (and Fake) Instagram Influencers, https://www.marketingprofs.com/articles/2018/39573/how-to-spot-authentic-andfake-instagram-influencers , Erişim Tarihi: 12.11.2020.

Braatz, L. (2017). \#Influencer Marketing on Instagram: Consumer Responses Towards Promotional Posts: The Effects of Message Sidedness, University of Twente, Master's Thesis.

Bughin, J., Doogan, J. \& Vetvik, O. (2010). A New Way to Measure Word-of-Mouth mMarketing, McKinsey Quarterly, 2, 113-116.

Byrne, E., Kearney, J. \& MacEvilly, C. (2017). The Role of Influencer Marketing and Social Influencers in Public Health, Proceedings of the Nutrition Society, 76, OCE3.

Campbell, C. \& Farrell, J. R. (2020). More than Meets the Eye: The Functional Components Underlying Influencer Marketing, Business Horizons, 1-11

Canöz, K., Gülmez, Ö., \& Eroglu, G. (2020). Pazarlamanın Yükselen Yıldızı Influencer Marketing: Influencer Takipçilerinin Satın Alma Davranışını Belirlemeye Yönelik Bir Araştırma, Selçuk Üniversitesi Sosyal Bilimler Meslek Yüksekokulu Dergisi, 23(1), 73-91.

Chatzigeorgiou, C. (2017). Modelling the Impact of Social Media Influencers on Behavioural Intentions of Millennials: The Case of Tourism in Rural Areas in Greece, Journal of Tourism, Heritage \& Services Marketing, 3(2), 25-29.

Childers, C., Lemon, L. \& Hoy, M. (2019). \# Sponsored\# Ad: Agency Perspective on Influencer Marketing Campaigns, Journal of Current Issues $\mathcal{E}$ Research in Advertising, 40(3), 258-274.

Chopra, A., Avhad, V. \& Jaju, S. (2020). Influencer Marketing: An Exploratory Study to Identify Antecedents of Consumer Behavior of Millennial, Business Perspectives and Research, 1-15.

Claesson, A. \& Ljungberg, N. (2018). Consumer Engagement on Instagram: Viewed through the Perspectives of Social Influence and Influencer marketing, Lund University School Of Economics and Management, Master's Thesis.

Clement, J. (2020). Number of Social Network Users Worldwide from 2017 to 2025, https://www.statista.com/statistics/278414/number-of-worldwide-social-networkusers/, Erişim Tarihi: 12.11.2020

Chetioui, Y., Benlafqih, H. \& Lebdaoui, H. (2020). How Fashion Influencers Contribute to Consumers' Purchase Intention, Journal of Fashion Marketing and Management: An International Journal, 24(3), 361-380.

Coates, A., Hardman, C., Halford, J. \& Christiansen, P. (2019). The Effect of Influencer Marketing of Food and a Protective Advertising Disclosure on Children's Food Intake, Pediatric Obesity,14 (10). 
Cohen, J. (2020). 3 key Data Stats on The State of Influencer Marketing Today, https://www.launchmetrics.com/resources/blog/influencer-marketing-report-2020 , Erişim Tarihi: 12.12 .2020

Coppola, D. (2020). Budget Allocated for Influencer Marketing by Italian Companies in 2019, by Type of Company and Campaign, https://www.statista.com/statistics/702038/influence-marketing-among-companies-initaly/ , Erişim Tarihi: 12.11.2020.

Cruz, F. (2018). Influencers: Micro \& Macro, https://www.tapinfluence.com/influencersmicro-macro/ , Erişim Tarihi: 12.11.2020

Çetin, F. A. ve Öziç, N. (2020). Bütünleşik Pazarlama İletişiminde Instagram Fenomenlerinin Satın Almaya Etkisi, Journal of Business Research - Turk, 12(1), 157-172

Dahan, E. (2016). Influencer Marketing May Be the Antidote to Ad Blocking, https://www.marketingprofs.com/opinions/2016/29369/influencer-marketing-may-bethe-antidote-to-ad-blocking , Erişim Tarihi: 12.11.2020.

Dangl, V. (2017). Social Media Influencer Marketing: An Empirical Study on Brand Sponsorships and the Effects on Credibility of Social Media Influencers in The Fitness Industry, Johannes Kepler University, Linz, Austria, Master Thesis.

De Veirman, M., Cauberghe, V. \& Hudders, L. (2017). Marketing through Instagram Influencers: The Impact of Number of Followers and Product Divergence on Brand Attitude, International Journal of Advertising, 36(5), 798-828.

Dogra, K. (2019). The Impact of Influencer Marketing on Brand Loyalty Towards Luxury Cosmetics Brands: Comparison of Generation Z and Millennial, Modul University, Vienna, Master Thesis.

Einarsdottir, V. (2017). From Celebrities to the Girl Next Door: Influencer Marketing with a Special Focus on the Social Media Platform-Instagram, University of Iceland, Bachelor Thesis.

Enberg, J. (2018). Instagram Leads as a Global Platform for Influencer Marketing, eMarketer, $1-4$.

Ewers, N. (2017). \#Sponsored -Influencer Marketing on Instagram, University of Twente, Master Thesis.

Femenia-Serra, F. \& Gretzel, U. (2020). Influencer Marketing for Tourism Destinations: Lessons from a Mature Destination, Information and Communication Technologies in Tourism , J. Neidhardt ve W. Wörndl (Eds.), 65-78.

Global Influencer Marketing Report. (2019). Global Influencer Marketing 2019 What to Know About Spending, Stories, Fraud and Microinfluencers, https://www.emarketer.com/content/global-influencer-marketing-2019 ， Erişim Tarihi: 12.11.2020.

Glucksman, M. (2017). The Rise of Social Media Influencer Marketing on Lifestyle Branding:A Case Study of Lucie Fink, Elon Journal of Undergraduate Research in Communications, 8(2). 
Goyette, I., Ricard, L., Bergeron, J. ve Marticotte, F. (2010). e-WOM Scale: Word-of-Mouth Measurement Scale for e-Services Context, Canadian Journal of Administrative Sciences, $27,5-23$.

Grafström, J., Jakobsson, L. ve Wiede, P. (2018). The Impact of Influencer Marketing on Consumers' Attitudes, Jönköping University, Bachelor Thesis.

Grave, J.-F. (2019). What KPIs Are Key? Evaluating Performance Metrics for Social Media Influencers, Social Media + Society , 1-9.

Gretzel, U. (2018). Influencer Marketing in Travel and Tourism, Sigala, M. ve Gretzel, U. (Eds.), Advances in Social Media for Travel, Tourism and Hospitality: New Perspectives, Practice and Cases, New York: Routledge, 147-156.

Gross, J. \& Von Wangenheim , F. (2018). The Big Four of Influencer Marketing A Typology of Influencers, Marketing Review St. Gallen, 2, 30-38.

Gustavsson, A.-S., Nasir, A. \& Ishonova, S. (2018). Towards a World of Influencers: Exploring the Relationship Building Dimensions of Influencer Marketing, Jönköping University, Bachelor Thesis.

Guttmann, A. (2020a). Influencer Marketing Platform Market Size Worldwide from 2017 to 2027, $\quad$ https://www.statista.com/statistics/1036560/global-influencer-marketingplatform-market-size/ , Erişim Tarihi: 12.11.2020

Guttmann, A. (2020b). Monthly Spending on YouTube Influencer Marketing Worldwide 2019, https://www.statista.com/statistics/1139121/monthly-spending-youtubeinfluencer-marketing-worldwide/ , Erişim Tarihi: 12.11.2020

Guttmann, A. (2020c). Instagram Influencer Market Size 2017-2020, https://www.statista.com/statistics/748630/global-instagram-influencer-market-value/ , Erişim Tarihi: 12.11.2020

Guttmann, A. (2020d). Average Spending on Influencer Marketing Campaigns According to Industry Professionals in the United States as of January 2019, by Tier, https://www.statista.com/statistics/1092670/influencer-campaign-spending-tier-usa/ , Erişim Tarihi: 12.11 .2020

Guttmann, A. (2020e). Leading Challenges of Influencer Marketing According to Industry Professionals in the United States as of January 2019, https://www.statista.com/statistics/617679/leading-challenges-of-influence-marketing/ , Erişim Tarihi: 12.11.2020

Hirokawa, R. \& Lowe, J. (2002). Katz and Lazarsfeld Revisited: Using Intermedia Theory to Enhance Health Campaigns, Global Health Conference, University of Iowa, Iowa,19-21.

Hoos, B. (2019). Uncovering The True Value Of Influencer Marketing On YouTube, https://www.forbes.com/sites/forbesagencycouncil/2019/12/11/uncovering-the-truevalue-of-influencer-marketing-on-youtube/?sh=51c080933572 , Erişim Tarihi: 11.12.2020 
https://influencermarketinghub.com/influencer-marketing-strategy/ (2018). Influencer Marketing Strategy: 11 Factors to Consider When Planning Your Next Influencer Campaign, Erişim Tarihi: 12.11.2020

https://influencermarketinghub.com/what-is-influencer-marketing/ (2020a). What is Influencer Marketing: An in Depth Look at Marketing's Next Big Thing, Erişim Tarihi: 12.11.2020.

https://influencermarketinghub.com/youtube-influencer-marketing-report/ (2020b). Youtube Influencer Marketing Global Spend Report: Q3, 2020, Erişim Tarihi: 11.12.2020

https://mediakix.com/influencer-marketing-resources/influencer-marketing-industrystatistics-survey-benchmarks/ (2019). Influencer Marketing 2019 Industry Benchmarks, Erişim Tarihi: 12.11.2020.

https://www.ana.net/content/show/id/48437 (2018). Advertisers Love Influencer Marketing: ANA Study, Erişim Tarihi: 12.11.2020

https://www.marketingprofs.com/articles/2018/40029/whats-next-for-influencer-marketing (2018). What's Next for Influencer Marketing?, Erişim Tarihi: 12.11.2020

https://www.smartinsights.com/online-pr/influencer-marketing/10-influencer-marketing/ (2018). Influencer Marketing Strategies You Need to Know, Erişim Tarihi: 12.11.2020

https://www.tapinfluence.com/blog-what-is-influencer-marketing/ (2015). Influencer Marketing, Erişim Tarihi: 12.11.2020

Hurt, J. (2017). Comparative Content Analysis Regarding Brand Management Through Influencer Marketing, John Carroll University, Masters Essays, 69.

Influencer Marketing. (2020). What Is an Influencer?, https://influencermarketinghub.com/what-is-an-influencer/ , Erişim Tarihi: 12.11.2020

Isosuo, H. (2016). Social Media Influencer Marketing, Jamk University of Applied of Science, Bachelor's Thesis.

Jaakonmäki, R., Müller, O. \& Vom Brocke, J. (2017). The Impact of Content, Context, and Creator on User Engagement in Social Media Marketing, Proceedings of the 50th Hawaii International Conference on System Sciences, http://hdl.handle.net/10125/41289, 11521160.

Jin, S., Muqaddam, A. \& Ryu, E. (2019). Instafamous and Social Media Influencer Marketing, Marketing Intelligence $\mathcal{E}$ Planning.

Johansen, I. \& Guldvik, C. (2017). Influencer Marketing and Purchase Intentions: How does Influencer Marketing Affect Purchase Intentions?, Norwegian School of Economics, Bergen, Master Thesis.

Johnson, J. (2020). Influencer Marketing in the UK- Statistics \& Facts, https://www.statista.com/topics/7119/influencer-marketing-in-the-uk/ , Erişim Tarihi: 12.11.2020

Kadekova, Z. \& Holiencinova, M. (2018). Influencer Marketing as a Modern Phenomenon Creating a New Frontier of Virtual Opportunities, Communication Today, 9(2). 
Krasniak, M. (2016). Social Influencer Marketing on the Rise: New Research. https://www.socialmediaexaminer.com/social-influencer-marketing-on-the-rise-newresearch/\#: :text=The\%20same\%20study\%20by\%20TapInfluence, the \%20respondents \%20finding\%20them\%20worthwhile. , Erişim Tarihi: 12.11.2020

Lee, S. \& Kim, E. (2020). Influencer Marketing on Instagram: How Sponsorship Disclosure, Influencer Credibility, and Brand Credibility Impact the Effectiveness of Instagram Promotional Post, Journal of Global Fashion Marketing, 11(3).

Lim , X., Radzol, A., Cheah , J.-H. \& Wong, M. (2017). The Impact of Social Media Influencers on Purchase Intention and the Mediation Effect of Customer Attitude, Asian Journal of Business Research, 7(2), 19-36.

Lou, C. \& Yuan, S. (2019). Influencer Marketing: How Message Value and Credibility Affect Consumer Trust of Branded Content on Social Media, Journal of Interactive Advertising, 19(1).

Martinez-Lopez, F., Anaya-Sanchez, R., Giordano, M. \& Lopez-Lopez, D. (2020). Behind Influencer Marketing: Key Marketing Decisions and Their Effects on Followers' Responses, Journal of Marketing Management, 1-29.

McCarthy, A. (2017). Marketers Unaware of FTC Social Media Guidelines Regulating Influencers, https://www.emarketer.com/Article/Marketers-Unaware-of-FTC-SocialMedia-Guidelines-Regulating-Influencers/1015341 , Erişim Tarihi: 12.11.2020

McCarthy, N. (2019). How Influencer Marketing Costs Exploded, https://www.statista.com/chart/19976/average-cost-of-a-sponsored-post-by-platform/, Erişim Tarihi: 12.11 .2020

Meiners, N., Schwarting, U. \& Seeberger, B. (2010). The Renaissance of Word-of-Mouth Marketing: A New Standard in Twenty-First Century Marketing Management?!, International Journal of Economic Sciences and Applied Research, 3 (2), 79-97.

Mumbengegwi, N. (2019). The Impact of Influencer Marketing on Consumer Based Brand Equity, Witwatersrand Business School,Johannesburg, Parktown, Master Thesis.

Nadanyiova, M., Gajanova, L., Majerova, J. \& Lizbetinova, L. (2020). Influencer Marketing and its Impact on Consumer Lifestyles, Forum Scientiae Oeconomia, 8 (2), 109-120.

Narassiguin, A. \& Sargent, S. (2019). Data Science for Influencer Marketing : Feature Processing and Quantitative Analysis, arXiv, 1906, 05911, 1-15.

Newberry, C. (2019). Influencer Marketing Guide: How to Work with Social Media Influencers, https://blog.hootsuite.com/influencer-marketing/ , Erişim Tarihi: 12.11.2020.

Patel, S. (2020). How You Can Build A Powerful Influencer Marketing Strategy in 2020, https://www.bigcommerce.com/blog/influencer-marketing/\#what-is-influencermarketing , Erişim Tarihi: 12.11.2020

Phung, L. \& Qin, L. (2018). Perception of Social Media Influencers: A Study on Evaluation of Social Media Influencer Types for Different Beauty Categories, Jönköping University, Bachelor Thesis 
Radey, T. (2015). Influencer Marketing: Why Relevance is More Important than Vanity Metrics, https://www.pr2020.com/blog/influencer-marketing-why-relevance-is-moreimportant-than-vanity-metrics , Erişim Tarihi: 12.11.2020

Riedl, J. \& Von Luckwald, L. (2019). Effects of Influencer Marketing on Instagram, Access Marketing Management, 1-37.

Schaefer, M. (2018). Word of Mouth Versus Influencer Marketing, https://businessesgrow.com/2018/11/12/difference-between-influencer-marketingand-word-of-mouthmarketing/\#: : :text=Influencer\%20marketing\%20is\%20even\%20working,to\%20small\% 20businesses $\% 20$ and $\% 20$ startups.\&text $=$ By $\% 20$ contrast $\% 2$ C $\% 20$ WOMM $\% 20$ is $\% 201$ ess within\%20rel , Erişim Tarihi: 12.11.2020

Shewan, D. (2017). 8 Influencer Marketing Strategies to Grow Your Reach, https://www.wordstream.com/blog/ws/2015/02/26/influencer-marketing , Erişim Tarihi: 12.11 .2020

Solis, B. (2008). The Art And Science of Blogger Relations, FutureWorks.

Stubb, C. (2019). The Gray Zone in Marketing Consumer Responses to Influencer Marketing, Abo Akademi University, Abo, Finland.

Sudha, M. \& Sheena, K. (2017). Impact of Influencers in Consumer Decision Process: The Fashion Industry, SCMS Journal of Indian Management, 14 (3), 14-30.

Szczurski, M. (2017). Social Media Influencer- A Lifestyle or a Profession of the XXIst Century?, Institute of Research and Journals (IRAJ), 1-5.

Şahin, D. (2019). Nüfuz Pazarlaması (Influencer Marketing): Youtuberlar Üzerine Bir Araştırma, Beykent Üniversitesi Sosyal Bilimler Dergisi, 12(2), 47-57

Tabellion, J. \& Esch, F.-R. (2019). Influencer Marketing and its Impact on the Advertised Brand, Bigne E., Rosengren S. (eds), Advances in Advertising Research X, European Advertising Academy, Springer, Gabler, Wiesbaden.

Talkwalker. (2018). What is Influencer Marketing? Your Ultimate Influencer Marketing Guide, https://www.talkwalker.com/resource/ebook-influencer-marketing-guide.pdf , Erişim Tarihi: 12.11.2020

Tankovska, H. (2020). Annual Revenue of Companies Who Work with Influencer Marketing in Denmark 2016-2019, https://www.statista.com/statistics/987640/annual-revenue-ofcompanies-who-work-with-influencer-marketing-in-denmark/ , Erişim Tarihi: 12.11.2020

Theocharis, D. \& Papaioannou, E. (2020). Consumers' Responses on the Emergence of Influencer Marketing in Greek Market Place, International Journal of Technology Marketing, 14(3), 283-304.

Trivedi, J. \& Sama, R. (2020). The Effect of Influencer Marketing on Consumers' Brand Admiration and Online Purchase Intentions: An Emerging Market Perspective, Journal of Internet Commerce, 19(1), 103-124. 
Veissi, I. (2017). Influencer Marketing on Instagram, Haaga-Helia University of Applied Sciences, Bachelor's Thesis.

Williamson, D. (2020). Influencer Marketing and the Path to Purchase, https://www.emarketer.com/content/influencer-marketing-and-the-path-to-purchase , Erişim Tarihi: 12.11.2020

Yağc1, S. (2019). Fenomen Pazarlama (Influencer Marketing): Dijital Pazarlamanın Kanaat Önderleri Üzerine Araştırma, Master's Thesis, İnönü Üniversitesi, Sosyal Bilimler Enstitüsü

Yodi, H. P., Widyastuti, S. \& Noor, L. S. (2020). The Effects of Content and Influencer Marketing on Purchasing Decisions of Fashion Erigo Company, Dinasti International Journal of Economics, Finance \& Accounting, 1(2), 345-357.

Zak, S. \& Hasprova, M. (2020). The Role of Influencers in The Consumer Decision-Making Process, SHS Web of Conferences, 74, 03014, EDP Sciences.

Zhang, Y., Lin, Y. \& Goh, K. (2018). Impact of Online Influencer Endorsement on Product Sales: Quantifying Value of Online Influencer, PACIS 2018 Proceedings, 201, 1-8.

Zietek, N. (2016). Influencer Marketing - The Characteristics and Components of Fashion Influencer Marketing, The Swedish School of Textiles, University of Boras, Master Thesis. 